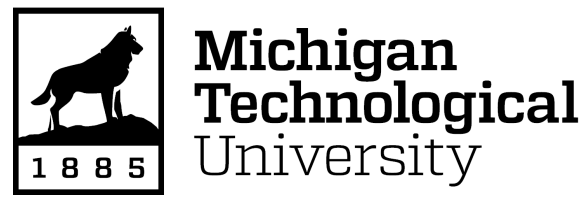

Michigan Technological University Digital Commons @ Michigan Tech

Dissertations, Master's Theses and Master's Reports

2018

SUSTAINABLE MANAGEMENT OPPORTUNITIES FOR THE FISHERY OF LAOANG, NORTHERN SAMAR, PHILIPPINES

Karl E. Palm

Michigan Technological University, kepalm@mtu.edu

Copyright 2018 Karl E. Palm

Recommended Citation

Palm, Karl E., "SUSTAINABLE MANAGEMENT OPPORTUNITIES FOR THE FISHERY OF LAOANG, NORTHERN SAMAR, PHILIPPINES", Open Access Master's Report, Michigan Technological University, 2018.

https://doi.org/10.37099/mtu.dc.etdr/743

Follow this and additional works at: https://digitalcommons.mtu.edu/etdr 


\title{
SUSTAINABLE MANAGEMENT OPPORTUNITIES FOR THE FISHERY OF LAOANG, NORTHERN SAMAR, PHILIPPINES
}

\author{
By \\ Karl E. Palm

\begin{abstract}
A REPORT
Submitted in partial fulfillment of the requirements for the degree of MASTER OF SCIENCE

In Applied Natural Resource Economics
\end{abstract}

MICHIGAN TECHNOLOGICAL UNIVERSITY

2018

(C) 2018 Karl E. Palm 
This report has been approved in partial fulfillment of the requirements for the Degree of MASTER OF SCIENCE in Applied Natural Resource Economics.

School of Business and Economics

\author{
Report Advisor: Gary Campbell \\ Committee Member: $\quad$ Latika Gupta \\ Committee Member: $\quad$ Kari Henquinet
}

School Dean: Dean Johnson 


\section{Acknowledgements}

I would like to express my great appreciation to Dr. Gary Campbell for patiently supporting me throughout my studies with Michigan Tech, both on campus and in the Philippines.

I would like to thank Dr. Kari Henquinet for helping me to prepare for my time in the Peace Corps and process the experience afterward. I also greatly appreciate the cultural perspective gained in meetings concerning overseas work.

I also thank Dr. Latika Gupta for encouraging and supporting me through my time at Michigan Tech, and for introducing me to the University hiring process.

I wish to express deep gratitude to the people of Laoang, Northern Samar for welcoming me into their community for two years, and to the Municipality of Laoang for allowing me to work and learn alongside them during my time in the Philippines.

Finally, I wish to thank my parents for their unwavering support and encouragement. 


\section{List of abbreviations}

\begin{tabular}{ll} 
BFAR & Bureau of Fisheries and Aquatic Resources \\
CFLC & Community Fish Landing Center \\
CLUP & Comprehensive Land Use Plan \\
CPUE & Catch Per Unit Effort \\
DOLE & Department of Labor and Employment \\
FAD & Fish Aggregating Device \\
FCM & Fish Catch Monitoring \\
FED & Fish Enhancing Device \\
FFA & Fisherfolks Association \\
HBO & Home Based Organizing \\
IFCRM & Integrated Fisheries and Coastal Resource Management Plan \\
LGU & Local Government Unit \\
MENRO & Municipal Environment and Natural Resources Office \\
MPA & Marine Protected Area \\
NPA & New People’s Army \\
UEPL & Peace Corps Volunteer \\
\hline
\end{tabular}




\section{Abstract}

Between September 2015 and August 2017 the author lived and worked in Laoang, a municipality in the province of Northern Samar in the Philippines. The author worked as a Coastal Resource Management Volunteer with the Municipal Environment and Natural Resources Office. This report discusses current and potential management strategies concerning the fishery of Laoang, particularly concerning the Fish Aggregating Devices (FADs) placed at the edge of the municipal waters. Information was compiled during the development of two 10-hectare Marine Protected Areas and a Fish Catch Monitoring program. Various strategies for both the FAD and coastal areas of the fishery are discussed, including enhanced environmental education and protection, limiting adding FADs to the municipal waters, and promoting tourism. While many of the programs discussed already exist in Laoang, these programs can potentially be expanded on to enhance the sustainability of the fishery to promote food security and income. 


\section{Introduction}

The environment and the economy are intricately linked. From mining to tourism to housing and other industries, the natural environments in which we live play a large part in market based decisions. This is particularly the case of local fisheries in the Philippines, where overfishing and environmentally destructive fishing practices have been the norm for decades. Here a growing population exerts ever more pressure on already taxed fisheries creating the need for management that considers the environment, incomes and food security of the population.

This report discusses current and potential management strategies concerning the fishery of Laoang, Northern Samar in the Philippines. Emphasis is placed on the anchored Fish Aggregating Devices (FADs) located at the edge of the municipal waters, though municipality-wide variables are also considered. The first section provides the history of the area and the data collection methods used. Section II discusses some of the variables affecting the fishery and economy in Laoang, while Section III introduces the current programs of the municipality. Section IV will discuss potential management strategies for sustained fishery output. Section V provides conclusion.

\subsection{History}

The Philippines was colonized by Spain, America, and then by Japan during WWII. Under Spanish rule Laoang was first developed into a mission center in 1627. "By the turn of the 1800's Laoang was exporting agricultural products such as; abaca (of the banana family), coconut oil, tuba (coconut wine), cattle and fabrics” (Municipality of Laoang 2013). The first Americans to arrive in Laoang were the First Nebraska Infantry Volunteers, landing in 1899 during the period of American colonialism. Through the 1950's and 60's Laoang saw the construction of the municipal GB Tan Memorial Hospital along with other infrastructure projects. Following the EDSA Revolution (People Power Revolution) of 1986 and the deposition of President Ferdinand Marcos, a member of the current ruling political family was appointed Officer in Charge of Laoang and was later elected Mayor in February 1988 (Municipality of Laoang 2013).

\subsection{Economy and Demographics}

As of the last census in 2007 the urban population of Laoang was 12,459 people and comprised of seven barangays (distinct villages within the municipality) in the town center. The rural population of the remaining forty-nine barangays was 43,737, totaling 56,196 . The Laoang unemployment rate in 2007 of persons over 15 years was 8.46 percent. Agriculture, Mining and Forestry was listed as the sector that employs the most Laoanganons, making up 43.27 percent of the jobs in the municipality (6,945 people). The second category is Wholesale and Retail Trade, Vehicle Repair (10.32 percent, 1,657 people), and the third largest employment sector in Laoang is Fishing, comprising 7.48 percent (1,201 people) (Municipality of Laoang 2013). The above numbers have likely 
changed in recent years, due in part to the introduction of FADs and the push to move away from illegal tactics. The above numbers may also be misleading as many people fish part time to make ends meet. Fishing is also disproportionately important for fisherfolk, their families, and others working within the fishing industry (such as fish traders) in many of the coastal barangays in Laoang. In more rural communities fishing is a primary source of food and income for a large portion of the population, as fisherfolk make up a smaller portion of the population in more urban areas.

Outside of the economic focal points listed above, the most notable source of employment is the local government. The municipality employs many Laoanganons, as does the University of Eastern Philippines Laoang (UEPL). In the private sector transportation, fishing and agriculture are the major economic areas. Rice and coconut plantations make up the majority of the agriculture although vegetables are produced for local consumption (often planted between the coconut palms). Many people are employed in the coconut business. They harvest and smoke dry coconuts for the production of copra (dried coconut meat used in making coconut oil); which is a key export of Laoang.

Though many transactions occur within the formal economy every day, large parts of the economy of Laoang are based on reciprocity or gift giving. Exchanging work or goods between community members is extremely common and the wide understanding of family networks supports this structure. Particularly in more rural areas (but also in the town center) people will not be allowed to go hungry, and though it is unlikely that any specific exchange takes place in that moment, transactions take place as a part of a tradition of kinship relations. Families remember and maintain longstanding relationships and reciprocal gifts make up many of the interactions in the Philippines outside of the formal economy. An example of this is when fisherfolks experience large catch days they will often give fish to other community members. With refrigeration rare in most barangays this is in part a way to prevent wasting, but also contributes to the culture of reciprocal gifts (Wilk and Cliggett, 2007).

In Tragedy of the Commons, Hardin noted that "freedom in a commons brings ruin to all" (Hardin 1968). This issue is at the heart of fisheries management throughout the world; commonly held resources see extraction rates beyond what they can afford, leading to the collapse of ecosystems and the extinction of species. Fisherfolk who maximize their own catch any way they can (including illicit tactics) increase their individual utility in the short term, but limit the opportunity for others (and their future selves) to maintain catch rates as increased pressure is placed on ecosystems. It is important for Laoang to manage its fishery in a way that allows continued environmental health and fishery output, without bringing ruin to the livelihoods of fisherfolk and the food security of the population through over limiting the ability to fish.

Commercial fishing boats have little immediate impact on the fishery of Laoang, as they are not allowed within the municipal waters. The affect that they have is with the highly mobile pelagic species (such as tuna). While they do not fish alongside the local 
fisherfolk, commercial vessels have an effect on the regional fishery, which affects the species passing through Laoang's waters. Commercial fishing is common in the Philippines, and a great deal of fish caught in Philippine waters are sold in national or international markets. This is not the case in Laoang, as the fishing that occurs locally ends up primarily in the municipal market or in the market of a neighboring municipality. Local fisherfolk, once registered to the FFA, have few checks on when or how much they fish.

\subsubsection{FADs}

Considering that fishing is the third largest source of employment locally, overfishing combined with destructive fishing practices has resulted in the deterioration of the fishery resources in Laoang and much of the Philippines over the last 60 years. In part to combat this and to ensure sustainable fish catch, the Philippine government (along with private interests) has been introducing FADs to the border of the municipal waters since 2016. The average catch while fishing at the FADs is generally much higher than fishing along the shore, and the species caught there are more valuable in the municipal market. The majority of reef fish do not make it to the municipal market but are consumed in the barangays. The FAD location is beneficial for local fisherfolk as their being within the municipal waters prevents direct competition from commercial fishing. Anchored, near-shore FADs introduced as government programs are a focus of this report; very little was found concerning private FAD structure. The Department of Labor and Employment (DOLE) and the Bureau of Fisheries and Aquatic Resources (BFAR) are national programs that work with municipal and provincial government units to implement FAD programs. The municipality of Laoang has a representative from BFAR that works closely with the LGU in implementing nationally sanctioned projects.

The use of FADs has developed from originally targeting logs and other naturally floating objects to placing floating devices in the sea. FADs are used throughout the world to attract pelagic species to a specific place allowing for catch rates that are much higher than fishing in the open ocean (Dagorn et al. 2013). Typically these devices are harvested using a purse- seine or ring net. These nets are used in Laoang approximately four times per year. For those FADs managed by the local government, private boats (who will sell catch outside of Laoang) are contracted to do this alongside the municipality, and the rest of the year they are fished by registered fishers or 'fisherfolk' using hand line tactics. The FADs in Laoang are physically simple structures. At the surface are buoys, a flag and often tire tubes, and in the water there is a structure with a screen and palm fronds. The structure is anchored with a large rope and a concrete block. These are static FADs as opposed to the free-floating design commonly seen on the open ocean. The palm fronds act as a shelter, drawing in small fish. These small fish then draw in tuna and other predatory deep-water species. Studies have noted that the catch value may be up to seven times the cost of FAD implementation depending on FAD longevity (Albert et al. 2014, Bell et al. 2015). 


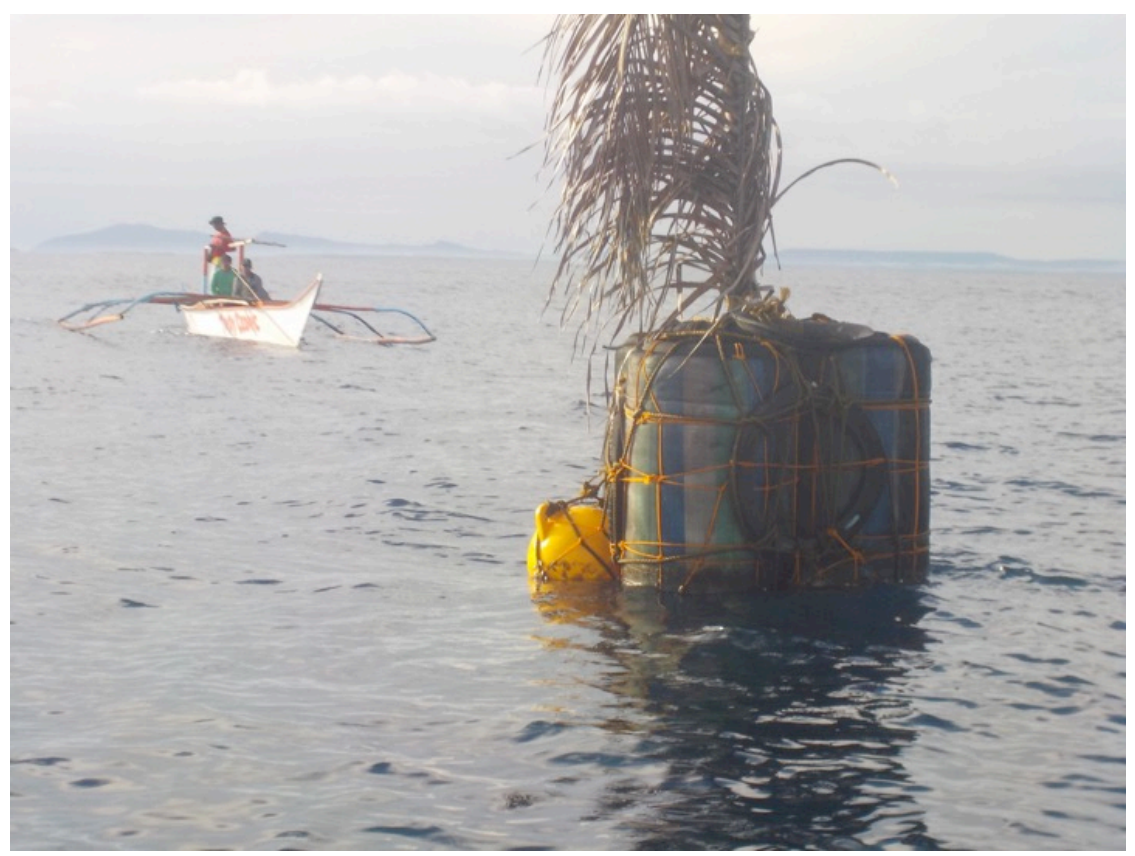

Figure 1.2.1. FAD within the municipal waters of Laoang.

\subsection{Data Collection and Personal Experience}

On July 5, 2015 the author arrived in the Philippines with other volunteers from Peace Corps Philippines Batch 274. After almost three months of training he was assigned to work in the Municipal Environment and Natural Resources Office (MENRO) of the Local Government Unit (LGU) Laoang. He lived and worked in Laoang for two years between September 2015 and August 2017, both attending and facilitating Peace Corps trainings and serving as a Safety and Security Warden of Northern Samar. While he had numerous assignments during his time with MENRO, the author's two primary projects were with the development of Marine Protected Areas (MPAs) and implementing a Fish Catch Monitoring (FCM) program with coastal barangays (villages). 


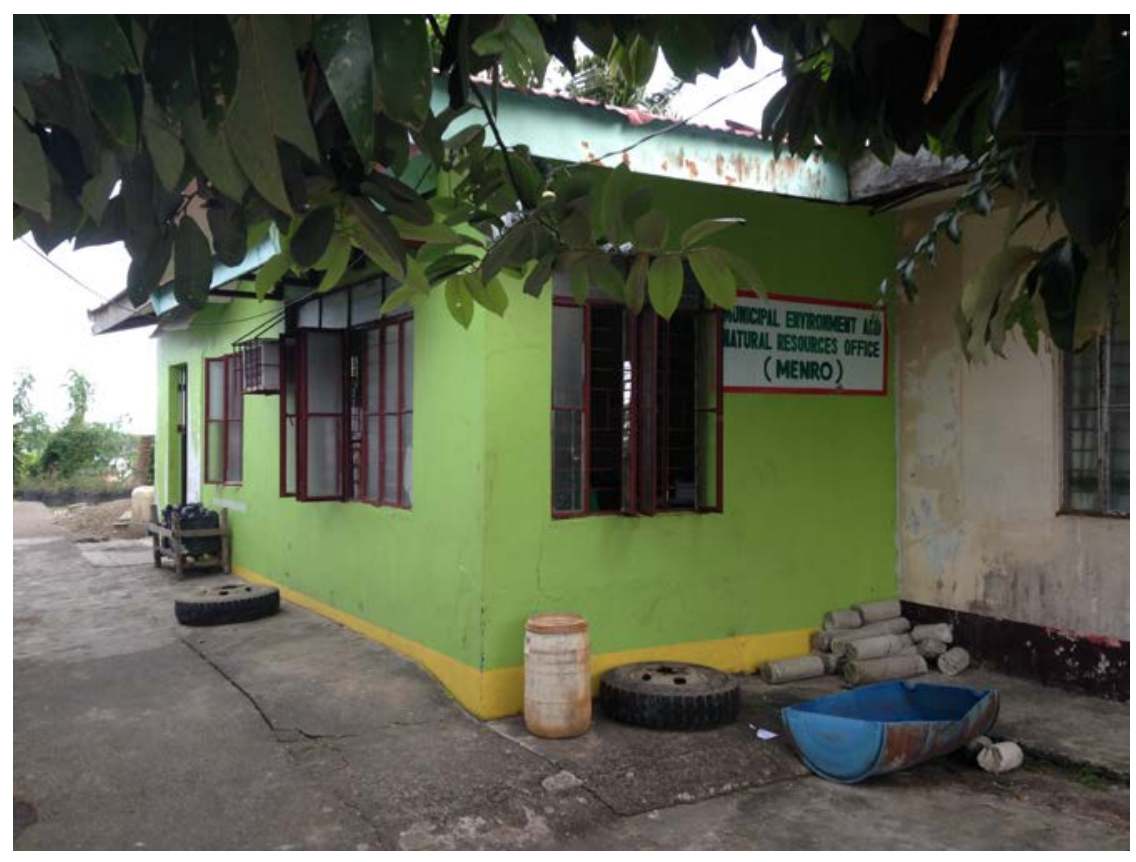

Figure 1.3. MENRO Laoang.

Marine Protected Area development was an important project to MENRO Laoang, and had already received significant attention by fall of 2015. Five MPA sites were selected and a guardhouse had been built at the first site when the author arrived. The first step in MPA development centered on writing a municipal ordinance to establish the area as no take/ no entry (meaning no one without expressed permission from the MPA Management Council could enter the site or take anything from it). Once written, meetings with the local barangay commenced to discuss the long-term benefits of a successful MPA. Once enacted by the LGU and barangay legislatures, the next role of MENRO was facilitating the monthly meetings of the MPA management council which consisted of members of the host barangay meeting with the caretaker and conducting monthly resource assessments of the mangrove, coral and seagrass located within the site. These meetings were reported back to the office, facilitating continued management between the barangay and the LGU. The second MPA site was installed and enacted in May of 2017, approximately a year after the first was formally established. In Laoang between 2015 and 2017, two 10 hectare areas with adequately established coral were set aside for the natural development of resources and ultimately a 'spillover' effect of mature fish into areas where fishing is allowed. Monthly assessments were conducted, and overall coral cover and fish populations were noted as improved by members of the MPA Management Council. By August 2017 the first MPA site saw notable improvement in coral growth and cover, as well as fish population and size. Fish size is an important variable as mature fish will have more developed offspring, which hastens the coming of future generations. As the site continued to be left undisturbed, shellfish, sea cucumbers and crabs appeared along the shore in larger numbers. These would have been picked out by 'gleaners' (shellfish collectors) had the site not been protected, and all 
play an integral role in ecosystem development. As the protected ecosystems continue to develop so will the opportunity for spillover into fishable areas.

The Fish Catch Monitoring (FCM) program went through two data collection iterations, one in 2016 and one (over a much more condensed time frame) in 2017. FCM involves collecting information about the catch of fisherfolk on a given day. In Laoang this included the total catch weight for that trip, the species caught, species catch weight and number of fish. The gear type, fishing location, and number of hours fished were also important variables collected. An example of the form used to log the data is included in the Appendix and has been translated to English.

The purpose of the FCM data collection was to gather information about the species being caught in specific locations to improve management capabilities in the future. Fish catch data was collected for local fisherfolk fishing with any gear type in ten coastal barangays over the course of one month (the entire process took several months each year). It was determined that longer collection periods would be too much given the volunteer workforce, and could potentially reduce support for the program. Trainings were held in every barangay discussing data collection methodology to determine what is being caught, where and with what gear. Local volunteers (members of the HBO program) were then asked to collect FCM data from returning fisherfolk. Data collection was administered by the MENRO Community Organizers along with heads of the HBO in the specific barangay. Teams of HBO volunteers were then assigned days to go out into the community and collect data on the catches of local fisherfolk. This data was then gathered by members of the office, consolidated and ultimately developed into barangay specific reports. While improvements were made in the 2017 data collection period, relying on volunteers resulted in inconsistencies in data collection methods and reporting. As a result, the FCM data of LGU Laoang presents a useful baseline of the main species being caught in different ecosystems of Laoang, catch weight trends, and the elements used to catch them, but should not be taken in full confidence. It was determined by MENRO that in the future, FCM would require hiring and formally training data collectors to collect accurate data over long periods of time. This however would involve an increased financial commitment. 


\section{Factors Affecting the Economy and Fishery}

Maintaining food security is a growing concern for many people in the Philippines, which holds one of the highest population densities on earth (World Bank 2017b). Food security is a particularly relevant topic for those who rely on fisheries resources. This section is divided into two parts: the first discussing some of the key variables that affect Laoang and the Philippines, the second portraying several key elements which concern the local fishery.

\subsection{Political Variables}

The majority of professional jobs in Laoang are through the municipal government or the University of Eastern Philippines Laoang. The government employs many schoolteachers, police officers, and other municipal employees. The University draws students from neighboring municipalities, creating demand for boarding houses and other services. Outside of this, many people are employed in transportation either working at the ferry boats between the islands, or driving 'trikes'; motorcycles modified to carry several people. There is also a notable market district in Laoang, and while the majority of these are family owned and operated, many will hire workers. The LGU gets federal funding for infrastructure projects (mainly road construction) that provide shortterm employment to many locals. Numerous fisherfolk that only fish part time are employed through these programs. Outside of these infrastructure projects, however, there are few options for fisherfolk to augment their income with part time or alternative jobs.

Many Laoanganons are employed in either fishing or agriculture (Municipality of Laoang 2013). For the owners of land, boats, or other forms of capital this can be relatively lucrative, however, the workers and fisherfolk often have low net incomes. Fisherfolk are often referred to as the 'poorest of the poor' in Laoang.

Remittances are another major variable in the economy of the Philippines (including Laoang) making up an estimated 10.2 percent of the Philippines' GDP in 2016 (World Bank 2017a). Many people in Laoang have either worked abroad or will speak with pride of their family members that are sending money home.

Due to its location on the edge of the Pacific Ocean, typhoons occur nearly every year in Northern Samar, ripping apart anything not made of heavy materials. These storms have a greater effect on those people already experiencing poverty, as their homes are typically made of light materials, such as thatched shingles and bamboo. Having to spend savings on rebuilding deters individual savings, as well as development at the community level. The LGU helps in rebuilding damaged boats and replacing lost fishing gear, but this is a slow process. Typhoons also damage coral, mangroves, and seagrass, setting back ecosystem development. In December of 2015 Typhoon Nona (Melor) devastated Northern Samar. The Peace Corps Volunteers (PCVs) were consolidated in a 
neighboring province for three weeks following the storm, returning to municipalities in which relief goods had not fully been distributed and repairs had not begun on many homes and buildings. This storm was hailed locally as the worst in memory since the 1980's and was a major setback for many Laoanganons. The coconut plantations, which

are a large part of the local economy, were set back for years as time for regrowth was needed across the province.

Another consideration in Laoang is the New Peoples Army (NPA), which has significant influence throughout Northern Samar. Formed in the 1960's, the NPA controls a large portion of the part of Laoang located on mainland Samar (the town center is located just off shore on the Island of Laoang) (Domingo 2013). Police are not allowed to visit these areas. The NPA makes it more difficult to enact policy that concerns upland elements of the fishery. For example, MENRO of Laoang has a program planting bamboo along upland riverbanks to reduce siltation and must be careful when working with barangays held by or near the NPA.

Political dynasties are common throughout the Philippines and have significant influence over local economies. One study that analyzed different elements of development noted that "the 'dynasty' variable has significantly negative effects on growth... the lack of competitive political system has been a main reason for the suboptimal policy choices and thus for the poor economic performances compared to its Asian neighbors” (Balisacan and Fuwa 2002). While the Philippine economy has done better in recent years, the dynasty variable remains relevant and is detrimental to growth.

\subsection{Fishery Variables}

The population of the Philippines has quadrupled since 1960 (World Bank 2017c). With the rise in population comes rising pressures within communities to sustain income and food security for those who rely on fisheries resources. In the 1950's the government created a program that helped local fisherfolk get boats and fishing supplies. Overfishing soon became a prevalent issue as the number of pounds of fish taken per year increased dramatically (Pauly \& This-Eng 1988). Starting in the 80's, fishing trips began to occur in which no fish were caught. This is a challenging cycle to break out of, as desperation to catch fish leads to further environmental degradation, and vice versa.

There are two significant areas within the fishery of Laoang. The first is coastal. This is comprised of the reefs and sandy/rocky areas just off shore as well as the brackish region where the Catubig River meets the ocean. The coastal area surrounds Laoang, Cahayagan, Batag, and Calachaan Islands, as well as the portion of Laoang that is on the Island of Samar. The second area is locally known as the 'Deep Sea' and is the area that stretches $10.1-15 \mathrm{~km}$ out from shore to the edge of the municipal waters (at $15 \mathrm{~km}$ ). The FADs are located in the Deep Sea and it is here that the larger pelagic fish are caught, primarily skipjack and yellowfin tuna. The use of FADs is a relatively recent practice in Laoang, only becoming a government program within the last two years. While fishing there the average catch rate is much greater and the price of the species caught is 
generally much higher than the reef species (Bell et al. 2015). The FAD location allows locals to fish without immediate competition from commercial fishing rigs, as commercial vessels cannot enter municipal waters.

Although it is common in both sections of the fishery to come home having caught nothing, the average catch is significantly higher while fishing the FADs than it is on the shore. Using data collected through the municipal Fish Catch Monitoring program, on average fishing in the coastal area yields approximately 5-7 kg per trip (depending on gear type and barangay) while average catch at the FADs is commonly over $20 \mathrm{~kg}$ per trip. The data collection methods used make it difficult to average catches between different barangays, however, the averages are comparable between the different villages and general takeaways have been used for this report. The average catch for fishing at the FADs varies greatly between the different barangays, ranging between $15.9 \mathrm{~kg} / \mathrm{trip}$ and $34.4 \mathrm{~kg} /$ trip. This is a large difference and is likely based on how the data was collected in the different communities. The FCM data for FADs should be taken with reservations, though the average is much higher than fishing the shoreline (MENRO 2017).

For the 2017 iteration of fish catch data collection, the average value of a fishing trip was computed using the price per kg and weight of each species caught. This was noted as catch value. For those using handline tactics at the FADs, the value less cost is commonly around 1,500 PhP, approximately US \$30. The average catch for those fishing along the shore is much lower than at the FADs for every gear type used (typically spear, net, or handline). The catch value less cost near the shore is approximately US \$5-10, depending on gear type. The cost of the trip was collected in the reports, though this number was not reported frequently in every barangay. The prices included in the fish catch data collection were misleading because many fish catches do not enter the formal economy but will be consumed in the communities in which they are caught. The consistency of this catch value occurring is also in question as it is likely that many fishing trips in which nothing was caught were not reported during FCM data collection. It is also likely that trips with large catches were reported at a higher rate than they normally occur (MENRO 2017). This data, though likely not completely accurate, helps to make the argument for making the infrastructural mechanisms more efficient (enhancing refrigeration and transportation abilities), as the catches have a large value that is not always seen by the fisherfolk.

Another comparison between fishing at the FADs and along the shore is the Catch Per Unit Effort (CPUE). CPUE is used to designate the level of effort required to catch fish, noted here as the kg of fish caught per individual fisherfolk per hour (kg/fisherfolk/hour). The CPUE while fishing at the FADs is on average much higher than along the coast. In the three barangays that listed fisherfolk using handline tactics at the FADs in the 2017 data, the CPUE range was between 1.65 and 2.47 $\mathrm{kg} /$ fisherfolk/hour. One barangay noted fishing with nets out in the deep sea, but this was not included in this report as it is a highly seasonal activity in the pursuit of flying fish. In only one barangay for spear users was the CPUE above $1 \mathrm{~kg} /$ fisherfolk/hour. Fishing in the coastal area is often closer to $.5 \mathrm{~kg} /$ fisherfolk/hour for every gear type. Similar 
skepticism should be applied to the accuracy of these numbers as noted in the catch value data above (MENRO 2017).

Similar to countrywide patterns, the coastal area of Laoang has experienced overfishing and the use of environmentally damaging fishing gear over the last several decades. "Critical coral reefs have been destroyed by dynamite fishing and the use of assorted poisons; mangrove forests have been cut for conversion to fish ponds and settlement areas, and sea grass beds have been affected by pollution, sedimentation and other human-related activities in the near-shore areas” (LGU Laoang, 2014). Though parts of the municipal waters have been doing comparatively well, these sites of higher fishery output are where fisherfolk will tend to congregate, giving the ecosystem little opportunity to recover and reducing fishery growth. This report advocates programs that will at least temporarily remove pressure on the local reefs to allow the fishery to recover. The common property aspect of marine resources results in fishing occurring in Laoang past the maximum sustained yield point. The fishers are fishing up until the point that it is no longer economically feasible, where the cost of fishing is equal to the profit from fish (for many gear types cost is quite low). Fishing at the point of cost in an open-access fishery is well past the sustainable point of fishing, especially with the historic (and current) use of dynamite and other illicit technologies that cause harm to the ecosystems (lowering biomass output) and take fish at levels unprecedented with legal small scale tactics (Field 2008).

It seems apparent that if the area were allowed to recover for a period and sustainable fishing methods were maintained, the coastal area of Laoang would supply the fisherfolk population with a much more reliable source of income and protein. A firsthand example of this is the author's work in developing Marine Protected Areas. A 10 hectare area that had been determined as a healthy site of Laoang (containing decent coral, seagrass, and mangroves) was set aside as a no entry, no take zone. Within one year the fish cover and size grew notably within the MPA, promising future fishery output. The FADs have a significant impact in reducing pressure on the coastal areas as well, incentivizing fisherfolk that are able to make the trip to fish the deep sea (Bell et al. 2015). 


\section{Current Programs in Laoang}

There are several programs in place through LGU Laoang designed to benefit the fisherfolk. This section presents the main programs and their intended effects. It discusses programs that have been undertaken throughout the coastal areas of the municipality and brings in programs more specifically turned towards the FADs.

\subsection{Coastal Programs}

The Home Based Organizing (HBO) structure is used for the dissemination of information and deciding how work can be organized in all of the barangays in which MENRO works. The HBO system divides households in the barangay into groups, often by proximity. Each group has a leader and a representative from every family. This program allows for the easy distribution of information if families are not represented at a meeting. It also makes it an effective way to organize volunteer work, as certain groups can take on parts of a project. The HBO system was utilized by MENRO during the data collection for the Fish Catch Monitoring program. Volunteers would select days to collect FCM data based on their HBO group. In this way no volunteer collected data on more than two days over the course of the month.

Another important organization in Laoang is the Fisherfolk Association (FFA). Every barangay has elected representatives that travel to the municipal center for regular meetings. The FFA allows fisherfolk to engage in ongoing fishery management, giving them the power to address concerns and potential solutions on an immediate level. The organization opens up lines of communication between the lawmakers and the fisherfolk.

One of the most direct programs that the municipality takes on is handing out gear to fisherfolk. Potential beneficiaries are identified by MENRO staff (those most in need), and gear is then distributed based on a lottery system per barangay. A small ceremony is held, and the handouts are typically attended by the mayor or other high-ranking municipal official. Most of the gear is designed for use in the coastal areas, to simply get people fishing; small boats easily paddled out to reefs, hand lines, and nets. Some boats that are given, however, are motor boats that could make it out to fish on the FADs or in other less accessible areas. This is a simple and effective way to improve the lives of the poorest fisherfolk in the municipality, by giving them a way to feed their families and make a small income.

Another element of the gear distribution program is in illegal gear exchange. Areas of Laoang still see the use of illegal gear, particularly in areas that are out of the way and not frequently patrolled. The most common gear exchanged is the push net, which is pushed along the coastal areas to sift for small crabs and shellfish. These are exchanged for gill nets or hand lines, removing environmentally destructive gear from use without destroying the livelihoods of the users. This program, instead of merely 
punishing people for using illegal gear, allows them to continue fishing and earning income.

The two Marine Protected Areas (MPAs) introduced in Laoang in 2016 and 2017 are a proven strategy for developing a sustainable fishery. In setting aside areas that have good coral, seagrass, mangroves, and fish cover, within a relatively short amount of time the MPA can see increases in fish population and size, as well as in ecosystem health. With improved fishery productivity comes the 'spillover' effect, in which developed fish leave the MPA and enter the areas of the municipality in which fishing is allowed. This allows for increased catch for local fisherfolk and ecosystem development that, if allowed, will spread beyond the confines of the protected area. MPA development can be difficult to enact politically, as fisherfolk can be hesitant to lose their fishing sites in the short term (particularly as the MPAs are created where fishing is good). However, community support is crucial for the success of any program of this nature and numerous meetings were held in both communities in which the MPAs were enacted to talk with local fisherfolk about the potential future benefits of sustainable resource management.

The Municipality of Laoang has taken on the development of alternative livelihood programs intended to provide income for fisherfolk and other locals. In the fall of 2015 there was a municipal program to make charcoal briquettes that employed a few people (less than ten). Unfortunately the facility was wiped out in Typhoon Nona. Another municipal project involved making concrete construction blocks that had been mixed with a small amount of recycled plastic bags. This program never really took off in sales with the municipality, but it was an interesting project for both recycling and alternative income development. In August of 2017 there were plans being implemented to set aside an area of the coast of Batag Island for sea cucumber farming. Sea cucumbers have a preexisting market within the municipality, being dried and shipped to China reportedly for use in medicines (sea cucumbers are not consumed in Laoang).

\subsection{Fish Aggregating Devices}

FADs were introduced to Laoang as a government program in April 2016. The 19 devices were not mapped until July 2017, but since their locations have been determined via GPS, more effective management can occur (due to an error in GPS mapping, only 18 devices appear in figure 4.2). The government can now more easily patrol the sites for commercial boats and maintain the structures. Another recent development that has the potential to greatly help FAD fishery development is the Community Fish Landing Center (CFLC). Funds were secured through the Bureau of Fisheries and Aquatic Resources' (BFAR) program encouraging the creation of CFLCs. The center has an open-air market area for fish trading and two office sized rooms. The plan is to develop a store that is run by the municipality that would cater to fisherfolk; selling basic gear and repair items. There is also space to have two deep-freeze style refrigeration units for catch preservation. Developing this "cold-chain infrastructure to facilitate trade" would be a valuable addition to the local economy (Bell et al. 2015). As of August 2017 these units had not yet been purchased by the municipality, however this would be highly 
beneficial as catch going to waste before market can be a concern on high-catch days. Construction of the CFLC was completed in Barangay Cahayagan in early 2017. This is a useful location, as it is one of the most northern points in Laoang and is a hub for FAD fisherfolk.

The boats that fish on the Pacific (Deep Sea) in Laoang are private. Many of these are owned by locals that own more than one boat and are crewed by community members that will split the catch with the owners. Catch that is not kept for consumption or given to other community members is typically sold to a fish vendor in the barangay, who then sells the fish in local markets (fish will also be sold in neighboring municipalities depending on the fish vendor). There are reports of fish being sold to further destinations in the Philippines, but this is quite rare. The money for fishing is not received by the fisherfolk until the catch has been sold, so there is commonly a wait period between fishing and income. The FADs that are part of government programs come from the Bureau of Fisheries and Aquatic Resources (BFAR), and the Department of Labor and Employment (DOLE). In Laoang, twenty-five registered members of the local FFA are permitted to utilize each government FAD. There are multiple fees that must be paid to maintain a membership as a registered fisherfolk that can utilize a FAD. The 'mayor's permit' for FFA registration is the most expensive with an annual fee of 500Php, and monthly fees of 20PhP. This is on top of gear registration, which varies from gear to gear but averages around 60Php annually. To register as a beneficiary of the FADs there is a one-time fee of 50Php, as well as $20 \mathrm{PhP}$ monthly. In all, with the one time 50PhP fee, the annual expense for FAD fisherfolk for licensing is approximately 1090 PhP, approximately \$21 USD. This is a considerable sum for most Laoanganons.

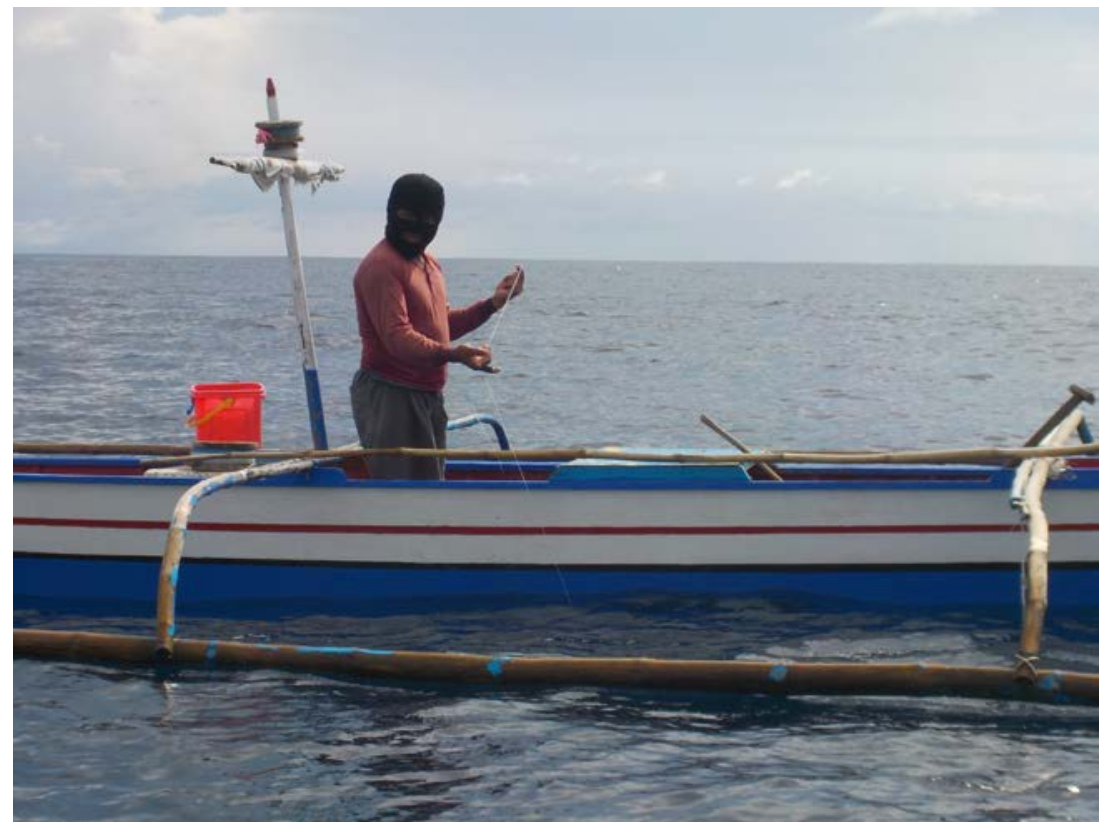

Figure 3.2. Fisherfolk at a FAD. 
The fisherfolk registered to the FAD have no limit to how often they can fish the site. They can also benefit from the harvest. Approximately four times per year, the FADs are harvested. For this to happen, the head of the local FFA contacts a commercial boat that is outfitted with a ring net that can fully encircle the FAD site (it is unclear how harvesters are selected). It was reported in an interview that the harvest is determined when there is a decline in fish caught with hand line tactics. Many of the local FFA members will go out to join in this harvest and harvest catch is distributed in part to the FFA. A portion of the catch goes to the company that manages the harvester and the remainder goes to the local FFA. Of the portion that goes to the FFA, 20 percent is for management and the other 80 percent is divided up for the registered fisherfolk. From the most recent harvest at the time of interview in June 2017, $500 \mathrm{~kg}$ of fish were caught and sold at $70 \mathrm{PhP} / \mathrm{kg}$, with a total value of $35,000 \mathrm{PhP}$. If $11,666 \mathrm{PhP}$ went to the harvester, the remaining 23,333 $\mathrm{PhP}$ would go to the local FFA. Of the 80 percent of this that goes to the 25 registered fisherfolk, each would receive approximately $746 \mathrm{PhP}$ ( 15USD) for the harvest. This leaves 4,666.6 PhP for the FFA management (along with required repairs and upkeep). While there are many fees associated with fisherfolk registration, the government does not interfere with fish pricing. This structure benefits the fisherfolk permitted to use the FADs a great deal, and if they work at the harvests that occur throughout the year, they could more easily afford the annual permits.

Splitting the harvester catch with registered fisherfolk is a beneficial system that provides increased public benefit to fisherfolk within the system; benefits that wouldn't necessarily happen with private FADs. There are however limitations to the program, as the cost of entry with the fisherfolk registration will prohibit those who cannot afford it of being eligible for the FAD program. Some people fish part time to make ends meet without being registered fisherfolk and are thus not eligible for municipal programs. There are also local political systems for how beneficiaries are determined and by whom, as beneficiaries are selected out of the local community by the local FFA. It is possible that the beneficiaries are not necessarily always those with the greatest need. The FAD program in Laoang has many benefits to those that are within the system but at this point it is not completely inclusive of Laoanganons. 


\section{Fishery Management Potential}

This section discusses potential future management programs for the municipality of Laoang as well as recommends the continuation or expansion of currently existing programs. The first subsection discusses potential programs for the coastal areas while the second discusses possibilities at the FADs.

\subsection{Coastal Area}

A relatively straightforward and inexpensive plan for promoting sustainable local fisheries would be the expansion of the current fisheries education program that is run by MENRO Laoang. There are discussions (often facilitated by MENRO Community Organizers) and presentations about the damage of illegal gear and fishing sustainably, but these are not always happening in every coastal barangay or necessarily being actively promoted in the schools. The development of an enhanced curriculum for both youth and adults about the potential for ecosystem development and the dangers of turning to illegal methods could improve sustainable resource management on a community level. Sustainable fishery development is untenable without community support. It is also important to note however, that discussion will not prevent people from fishing out of desperation.

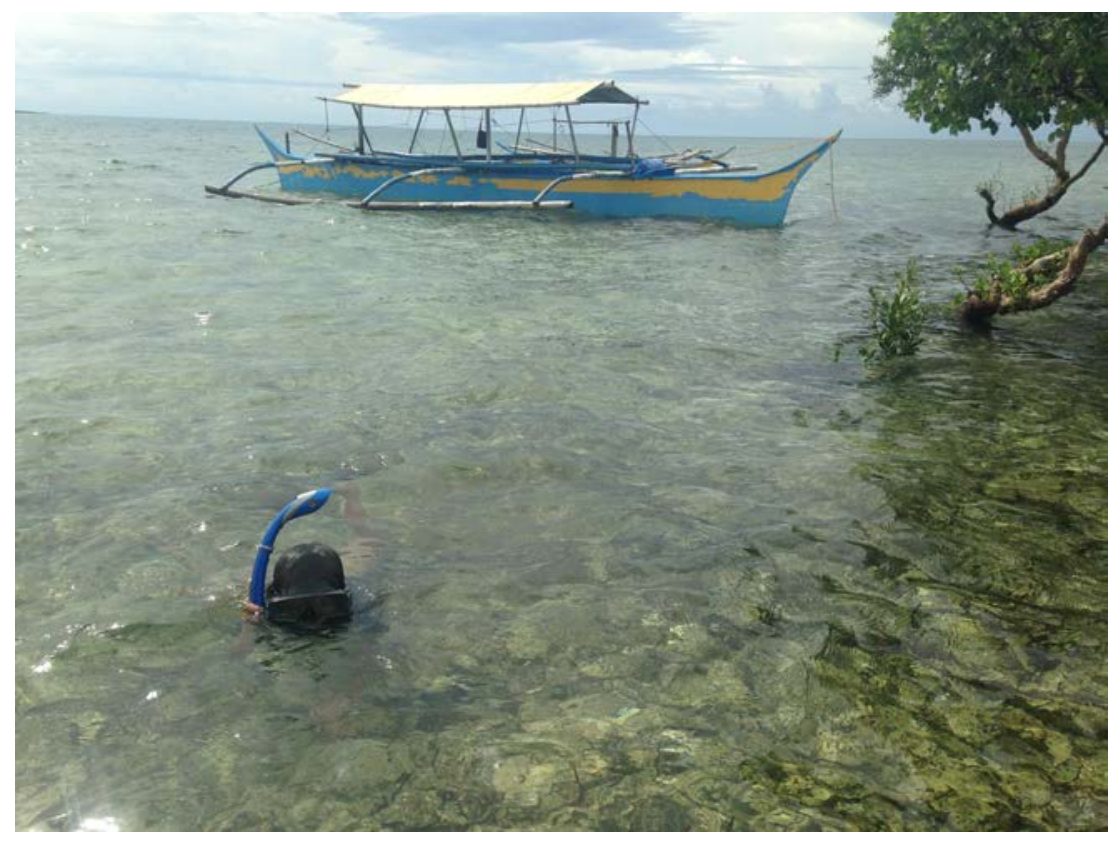

Figure 4.1. Local child explores the coastal waters of Laoang.

Another straightforward, albeit more expensive, tactic for sustainable fishery management is the expansion of the local enforcement team to further patrol the municipal waters. There is currently a team in MENRO that will get out for patrol 2 to 3 
times per week. There are areas of the municipality that have the reputation of commonly seeing the use of illegal fishing methods, particularly the least populous and farthest points from the city center. Having people that are out in the communities and on the water talking to fisherfolk would have the potential to open discussions about sustainability while ensuring that national and local regulations are followed. When the Community Fish Landing Center (CFLC) develops into a facility that is utilized for fish trading and storage, it would be effective to have someone working there full time who could collect catch data as the boats return to the center. This, if managed correctly, would provide two highly useful outcomes in both managing the use of the FAD government program and obtaining further useable information for up to date sustainable fishery management. If it is utilized, the CFLC could be good for the local economy as fish storage would reduce fish wasting in the heat. The site would also improve efficiency in trading fish throughout Laoang, as well as enable the expansion of trade throughout the province.

The further development of alternative livelihood opportunities or long term employment programs are a potential strategy that would effect the economy of Laoang and could have a lasting effect on the fishery. Promoting other forms of employment for fisherfolk utilizing the coastal areas (and particularly those using illegal methods) would provide them with a source of income and remove pressure from the reefs. Not all coastal fisherfolk should be alternatively employed, but incentivizing some to do so would help mitigate the effects of overfishing. The LGU currently gets funds for infrastructure programs and many part time fisherfolk will work on road or municipal building construction. Creating long term works programs or incentivizing private job creation would do a great deal for Laoang. Developing a works program for locals would align with the political norms of the Philippines as these sorts of programs are common. Expanding on the programs already set in motion would be a beneficial start.

The continuation and expansion of the municipal Marine Protected Area (MPA) program would potentially be a valuable strategy in expanding the biomass output of the local fishery. Five MPA sites were originally planned by the LGU, and at this point only two have been fully implemented. Instituting the remaining three sites would bring the total area of the local MPA program to 50 hectares, still a small portion of the total fishing area, but with five different locations established the potential benefit could be great. In establishing the second MPA site, the governing unit of the local barangay was more committed from the start than had been the barangay leaders of the first site. It was noted that they had heard of the first MPA being established and wanted to replicate this program. In areas in which establishing MPAs is politically viable (without pushback from fishers) MacNeil et al. note that "well-enforced marine reserves can support a full suite of reef fish functions given enough time to recover" (MacNeil et al., 2015).

There is little in the way of tourism in Eastern Northern Samar. While there are amazingly beautiful sites, Samar as a whole is considered to be difficult to access relative to other parts of the Philippines. There are only a few flights in and out of Samar every week and there are very few resorts in the Laoang area (and entire region of Northern 
Samar). The presence of the New People's Army (NPA) and the frequency of typhoons are further considerations in developing tourism. While it is a geographically beautiful region there are obstacles in the way of bringing in tourists from other regions or countries. This can be seen as an opportunity however, in that Laoang is well placed to initiate ecologically sustainable tourism. With the development of MPA's over the last two years, in time, the sites could become a draw for snorkelers and divers. The municipality is in a prime place to enact regulations that would promote tourists, and benefit the local ecosystem and economy. Bringing in snorkelers to MPA sites for example, would provide local employment opportunities and could be done in a way that would disturb the ecosystem in the smallest extent- by enacting policies about touching coral, placing anchor buoys around reefs, and only entering the water in relatively deep areas. In many places of the Philippines sites with well-developed ecosystems will invite tourists who then proceed to damage corals or other natural elements, thus depleting the health of the area. The investment of protecting and maintaining reefs does not come close to the potential benefits of tourism to the Philippines. That practice, paired with sustainable fishing methods, has the potential for a great economic impact on the municipality. The municipality could also charge fees to tourists upon entering protected sites. This would positively impact the reefs as money earned from tourism could be put back into coral reef preservation and regulation (White et al. 2000).

\subsection{FADs}

The continuation and enhancement of FAD management is crucial for maintaining fish stock and sustainable catch rates. This section will discuss several ways that the FAD program could be expanded starting with an enhanced enforcement program. The enhancement of the current enforcement system discussed in the previous subsection would be a positive movement towards sustainability. Sending a team to patrol the FAD area occasionally would improve enforcement and understanding of the conditions at the FADs (to note required repairs etc.) as well as help with education surrounding the development of further regulation for the FADs as they occur. This enforcement team would act in some capacity as a liaison between the fishing community and the municipal government, relaying information and opening discussions. 


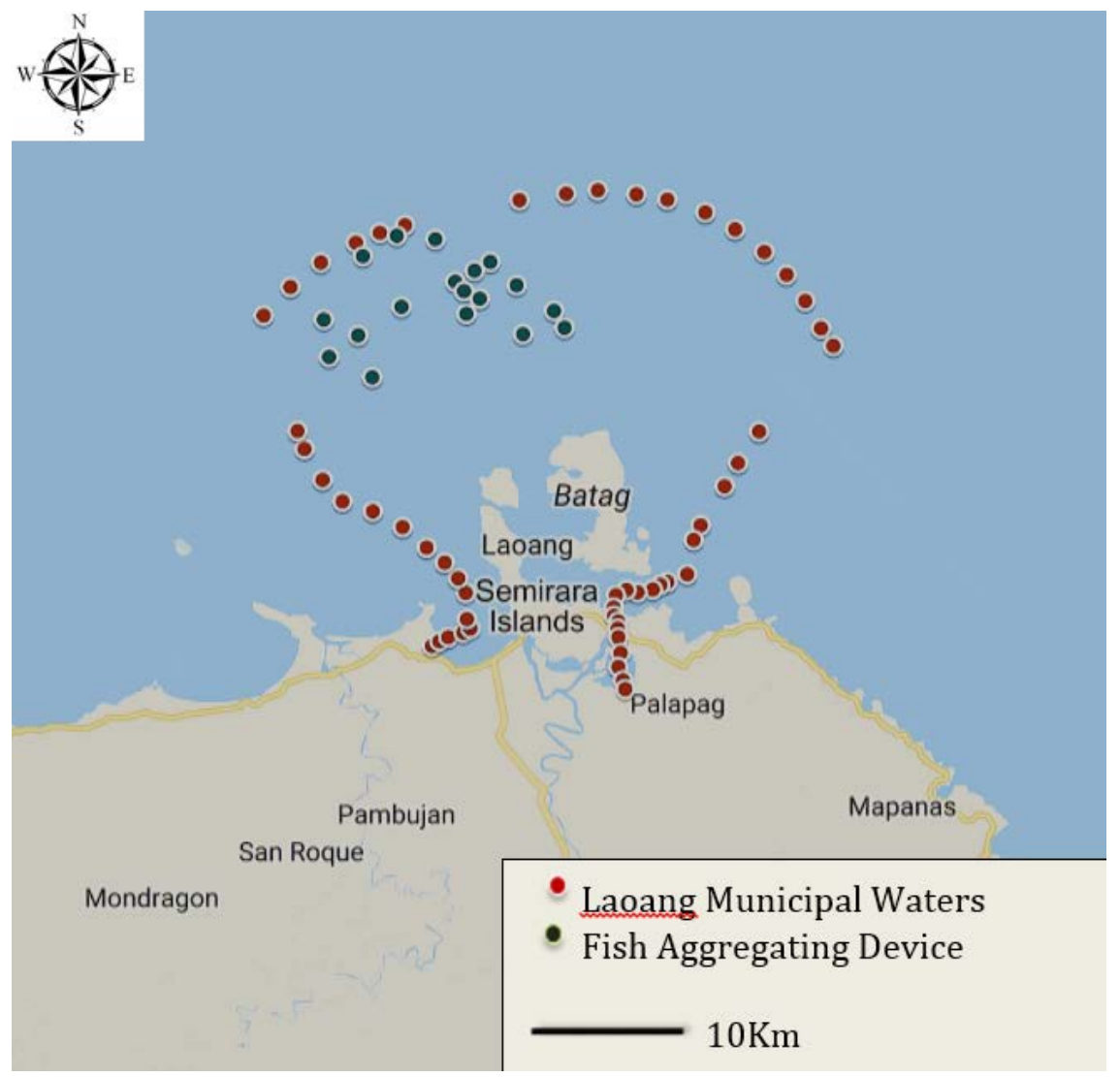

Figure 4.2. Laoang municipal waters and 18 FAD Locations

The spacing of the FADs from one another is a concern that could improve the efficiency of the fishery. As argued by Cabral et al., placing too many FADs too close to one another will "saturate" the fishery which "homogenizes the distribution of fish stock and effectively reduces the efficacy of FADs in aggregating fish” (Cabral et al. 2014). Based on the GPS mapping done by the MENRO office in July of 2017, the FADs are clustered quite closely together, within $5 \mathrm{~km}$ of one another, and some under one $\mathrm{km}$ from another FAD. The FAD cluster can be seen in Figure 4.2, in relation to the municipal waters. The FADs that were located in 2017 are all to the Western half of the municipal waters. According to federal law, the municipal FADs can only be placed between 10.1 and $15 \mathrm{~km}$ from shore (RA 8550, 1998). While all identified FADs are outside of the $10.1 \mathrm{~km}$ range, the recorded FADs are only located in approximately half of the potential area. Ideally FADs should be approximately $20 \mathrm{~km}$ from one another to maintain the attractive element of every device. FADs have an attractive radius for tuna of approximately $10 \mathrm{~km}$, and often the tuna are passing through the area as opposed to formally 'aggregating' around the device (Cabral 2014). Girard et al. contend that tuna are attracted to the FADs, but do not necessarily stay clustered around one- more often merely passing through. Girard et al. note that tuna can be 'on' or associated with a given FAD within a $1.8 \mathrm{~km}$ radius from the device, and will often move from device to device, spending small amounts of time at each and only occasionally 'aggregating' at a specific 
site. Moving the existing FADs farther apart would be a major project for the municipality, but could increase the efficiency of every device and would promote sustainable catch (Girard et al. 2003). Although there is not enough space in the municipality to have the distance recommended between every existing device as the municipal waters at their largest are $36 \mathrm{~km}$ from East to West, additional spacing would help to improve catch rate and sustainability for the FADs in Laoang.

An option for the regulation of FAD spacing would be to restrict the number of new FADs that would be implemented on the grounds that it reduces the efficiency of every device (there is effectively not enough space for many devices to remain effective). Spreading the devices out as much as possible would require a great deal of work, but reducing the saturation of FADs over the relatively small available space would likely be beneficial in the long run. Though enforcing these rules would be difficult, improving the efficiency of every fishing trip to the FADs would benefit the local economy; there is a large time commitment in travelling out to the devices, as well as fuel costs.

A possibility for improved fishery sustainability in Laoang would be developing a Fish Enhancing Device (FED) area. Structured the same as FADs, these devices would work in the same ways as MPAs do in coastal areas, serving as a protected area for pelagic fish to gather (and pass through into other areas), producing a spillover effect. This could be managed in various ways, if only as a FAD that was harvested with less frequency, with very restricted fishing regulations, or with no fishing at all on those specific devices (Cabral et al. 2014). This practice was started in Southern Thailand, and used as floating artificial reefs to support local fish stock (FRA-SEAFDEC 2010). Cabral et al. note that while near shore FADs improve fishing success and can mitigate the stress on a taxed coastal fishery, "the management challenge is how to encourage the fishing community to be compliant with access rules to FADs. Utilizing FADs with strict control on access and use creates a good balance between the community benefits and resistant stock” (Cabral et al. 2014).

Whether some devices become FEDs full time or not, finding a balance to mitigate stress on the local fishery is important for sustained fishery health. A very small number of FEDs could serve as a MPA in the 'Deep Sea' sector of the fishery of Laoang. While it may be difficult to find a management strategy that is both environmentally sustainable and doesn't limit fisherfolks access to income, management of FADs (or FEDs) is important for long-term fishery health. At a minimum this should be done through continued fish catch monitoring and assessment, noting catch levels over time. Short closed seasons could be considered to allow fish stocks to replenish, though this would have to be done carefully so as not to significantly deplete access to food security and income. Relatively little has been found concerning FEDs and it is difficult to predict the specific outcomes of their implementation. However, even if only on an experimental level providing a haven for pelagic species would be a step towards sustainable management. 
One of the key arguments concerning the sustainability of FADs is about bycatch (unwanted species, commonly associated with net use) which happens little with the hook and line users that frequently utilize Laoang's FADs. The harvests are a more complex situation regarding sustainability but are occurring infrequently throughout the year. Bycatch in Laoang, given the local culture of utilizing everything that is caught, seems unlikely in itself, as even if species that are caught are not useful in a market sense, they will be consumed (this has also been a practice with protected species, though education and protection programs have started to take hold).

It would likely be a useful step for Laoang to develop an ordinance formally regulating the FADs at the municipal level. Even if basic steps were taken towards management, it would set up the basis for sustained management. There is a management structure in place for the FADs that are coming through government programs, though at this time there is little in the way of regulation for privately owned FADs. The FAD program in Laoang is a relatively new one, and this report sees merit in implementing baseline sustainability programs from the start. 


\section{Conclusion}

Two of the key approaches to fisheries management noted by Field are being utilized in Laoang. The restriction of access to fishing to avoid the problem of open access is occurring through the development of MPAs which limit, if only on a small scale, the spaces that can be fished. Access restriction is also occurring through the registration of fisherfolk. By collecting information on people and by obtaining a small fee, the municipality is determining how many fisherfolk and what gear types are being used in what areas and potentially limiting registry (Field 2008). The regulation of fishing practices is also being actively taken on through reducing the use of illegal gear and promoting licit practices. Catch limits do not exist in Laoang at this point, outside of not keeping species that cannot be kept.

All of the management strategies listed in an article of Bell et al. are underway in some capacity in Laoang. The strengthening of community-based sustainable management strategies is occurring in several ways, from developing the FFA to illegal gear exchanges. Through the FCM program, indicators have started to be collected and developing MPAs at the local level is an example of positive working relations between the community and the LGU. The awareness and public educational campaigns have been occurring for some time, and the municipality has taken on the implementation of numerous government programs and regulations (Bell et al. 2009).

The FADs located within the municipal waters of Laoang are already being managed in a way that is far more sustainable than many FADs currently are. There are institutions, both government and local, that are taking on many of the recommended management tactics. This paper has not argued that what is happening in Laoang is negative (many very positive practices are underway) but that a fine tuning of management strategy would be beneficial in ensuring sustained catch rates. By collecting information on what is happening within the municipal waters, through activities such as fish catch monitoring and meeting with the Fisherfolks Association, forward thinking strategies can be implemented that both encourage sustained fish catch and environmental health.

The municipality has already looked into the possibility of a long term Fish Catch Monitoring (FCM) program and with funding would have the ability to note catch trends throughout the municipal waters, notably at the FADs. The development of MPAs is another program that has potential long-term benefits for the municipality. Maintaining strong relations between the community and local government offices is a mainstay of politics in Laoang and this is imperative for developing continued relations and program sustainability. Gear exchanges and other programs intended to reduce the use of harmful or illicit fishing is also very beneficial to the environmental sustainability of Laoang. Future potential programs are in many cases an expansion or slight modification of what is already occurring. From focusing on the distancing of FADs, potentially the development of FEDs or the development of infrastructure for tourism, the potential for sustainable management in Laoang is immense. 
This report has been an attempt to discuss potential viable management solutions for the fishery of Laoang, Northern Samar, Philippines. Management potential was discussed throughout the municipality but certain focus has been given to the FADs at the edge of the municipal waters. An effort has been made to holistically consider variables to paint a picture of the current state of the fishery. 


\section{Works Cited}

Albert, Joelle A., et al. "The Contribution of Nearshore Fish Aggregating Devices (FADs) to Food Security and Livelihoods in Solomon Islands.” PloS ONE, 9(12), 2014.

Basilican, A., and Fuwa N. "Growth, Inequality and Politics Revisited: A Developing Country Case.” Economic Letters 79.1 (2002).

Bell, Johann D., et al. "Optimising the Use of Nearshore Fish Aggregating Devices for Food Security in the Pacific Islands.” Marine Policy, 56, 2015, pp. 98-105.

Bell, Johann D., et al. "Planning the Use of Fish for Food Security in the Pacific" Marine Policy, 33(1), 2009, pp. 64-76.

Cabral, Reniel B, et al. "Modeling the Impacts of Fish Aggregating Devices (FADs) and Fish Enhancing Devices (FEDs) and Their Implications for Managing Small Scale Fisheries.” ICES Journal of Marine Science, vol. 71, no. 7, 22 Jan. 2014.

Dagorn, Laurent, et al. "Is It Good or Bad to Fish with FADs? What Are the Real Impacts of the Use of Drifting FADs on Pelagic Marine Ecosystems?” Fish and Fisheries, vol. 14, 2013, pp. 391-415.

Domingo, Francis. "Explaining the Sustainability of the Communist Party of the Philippines- New People’s Army.” Small Wars Journal, 4 Oct. 2013.

Field, Barry C. Natural Resource Economics: An Introduction. 2nd ed., Waveland Press, Inc., 2008.

FRA-SEAFDEC. The Proceedings of the Fisheries Research Agency Southeast Asian Fisheries Development Center (FRA-SEAFDEC) on Artificial Reefs for Fisheries Resource Recovery. Minami-Aoyama Kaikan Hall, Minato, Tokyo, Japan, 11 November 2010. 
Girard, Charlotte, et al. "FAD: Fish Aggregating Device or Fish Attracting Device? A New Analysis of Yellowfin Tuna Movements around Floating Objects.” The Association for the Study of Animal Behavior, vol. 67, 6 July 2003, pp. 319326. Elsevier Ltd.

Hardin, Garrett. “The Tragedy of the Commons.” Science, vol. 162, 13 Dec. 1968.

Local Government Unit Laoang (LGU Laoang). Integrated Fisheries and Coastal Resource Management Plan 2014-2024. Municipality of Laoang, Northern Samar, Republic of the Philippines, 2014.

MacNeil, M. Aaron, Graham, Nicholas A. J., Cinner, Joshua E., Wilson, Shawn K., Williams, Ivor D., Maina, Joseph, Newman, Steven, Friedlander, Alan M., Jupiter, Stacy, Polunin, Nicholas V. C., McClanahan, Tim R., 2015. "Recovery Potential of the Worlds Coral Reef Fishes” Nature 520, 341-344.

Municipal Environment and Natural Resources Office (MENRO). Fish Catch Monitoring Interviews. Municipality of Laoang, Republic of the Philippines, 2017.

Municipality of Laoang Planning and Development Office, "Comprehensive Land Use Plan 2013-2022.” vol. 1: Demographics, Republic of the Philippines, 2013.

Pauly, D., and C. This-Eng. "The Overfishing of Marine Resources: Socioeconomic Background in Southeast Asia." Ambio 17.3 (1988): 200-06. JSTOR.

RA 8550, 1998 Republic Act No. 8550. Republic of the Philippines, Chapter 2, Article 1, Section 18(a), 1998.

White, A.T., H. Vogt, T. Arin, 2000. "Philippine Coral Reefs Under Threat: The Economic Losses Caused by Reef Destruction” Marine Pollution Bulletin 40(7) 598-605.

Wilk, Richard R., and Lisa C. Cliggett. Economies and Cultures: Foundations of Economic Anthropology. Westview Press, 2007. 
World Bank Group, “Personal Remittances, Received (\% of GDP): Philippines.” The World Bank, 2017a.

World Bank Group, “Population Density (people per sq. km of land area).” The World Bank, 2017b.

World Bank Group, “Population, Total: Philippines.” The World Bank, 2017c. 


\section{A Appendix}

Appendix A.1 holds the form for the Fish Catch Monitoring program in Laoang for 2017, it has been translated into English from the original Waray-Waray. The write ups for the FCM interviews are in Appendix A.2, summary fish catch data is in Appendix A.3, and copyright documentation is in Section $\mathrm{B}$.

\section{A.1 Fish Catch Survey Form}

\section{FISH CATCH SURVEY FORM}

Barangay: Date: Name:

Gear Type: Time of Day:

$$
\text { Class Number of people in the boat }
$$

Boat:

Fishing Location: Hours spent Fishing (hr)

Cost of the Trip: Boat Owner:

Share of Catch Kept:

Weather:

Remarks:

\begin{tabular}{|l|l|l|l|}
\hline Species of Fish & Fish Count & Total weight (kg) & $\begin{array}{c}\text { Price Per kg } \\
\text { (PhP) }\end{array}$ \\
\hline & & & \\
\hline & & & \\
\hline & & & \\
\hline & & & \\
\hline & & & \\
\hline
\end{tabular}




\begin{tabular}{|l|l|l|l|}
\hline & & & \\
\hline & & & \\
\hline & & & \\
\hline
\end{tabular}

Enumerator(s):

Checked by:

\section{A.2 Fish Catch Monitoring Interviews}

Two interviews were conducted with prominent leaders of FAD work in Laoang. One person works at the Barangay level and has an immense working knowledge of the details of the program at the village level, while the other worked at the municipal level and discussed these programs from a broader perspective.

Prepared questions were used for both interviews: What is the physical structure of the FADs? How many are there? Where are they located? How long have they been in the municipality? How many barangays have FADs? How many per barangay? How many fisherfolk are utilizing them? Are they privately or publicly owned? How are they purchased? How are they managed? Who manages them? Are there fees being collected? How are profits managed? How is catch sold? What are the future management plans of the municipality? Are there environmental concerns being addressed?

Fish Aggregating Device (Payaw) Interviews

Karl Palm

\section{SUMMARY OF INTERVIEW 1}

The Fish Aggregating Devices (FAD) are physically quite simple structures. At the surface are buoys and a flag (and often tire tubes), and below this is a structure with a Styrofoam screen, and palm fronds. The structure is anchored with a large rope, and held by a concrete sinker. The palm fronds act as a food source, drawing in small fish. These small fish then draw in tuna and other larger deep water species (tuna). This is what the local fisherfolk are after.

Interviewee was unsure about how many FAD were in other Barangays, but in the Barangay of the Interviewee there are nine FAD sponsored by two different government institutions. Four come from the Bureau of Fisheries and Aquatic Resources (BFAR), and five are from the Department of Labor and Employment (DOLE). There are also other FAD that are private within Laoang. 
It was reported that the FAD are at the edge of the municipal waters. Mainly between 10$15 \mathrm{~km}$ from shore, around a one hour trip at the nearest (Municipal waters extend to $15 \mathrm{~km}$ off shore). The FAD program started in April 2016, and has seen success in improving local fish catch. Five barangays have FAD.

In the host barangay, there are 25 beneficiaries per FAD, that can fish the structure using hook and line whenever they choose. Approximately four times a year however, they harvest the FADs. This is done through a harvester (big boat), and many of the hook and line users registered to the specific FAD. They go out and catch tons of fish out of the FAD. When to harvest is decided by the head of the local Fisherfolks Association.

In a harvest, the catch is mostly sold through the company that runs the harvester boat, though it can also move through Fish Vendors. Once money has been collected, it is distributed $1 / 3$ to the harvester, and the rest is distributed to the beneficiaries of the FAD (including management, 20\% cut). The fisherfolk get $80 \%$ of the portion that goes to the barangay.

During regular catch (non harvest), catch is distributed through the local fish vendors, who will sell throughout the municipality. Once the catch has been liquidated the fisherfolk are paid for their catch.

All fisherfolk that are beneficiaries of government FAD are registered as fisherfolk with the Municipality. On top of this registration, they pay 50 pesos (US \$1) to register, then 20 Pesos/month ( 40 cents) to maintain membership with the FAD.

The fish vendors get to keep a cut of the sales that they make. During the harvest, they are cut in with the FAD organization.

Petty cash for FAD upkeep/maintenance is also a part of the harvest profit, this is a part of the portion that goes to the harvester owner.

\section{SUMMARY OF INTERVIEW 2}

Between the five Barangays that have FAD as government projects there are 16 total. Nine in one barangay, then 3 in another, 2, and two barangays have one FAD. These are only the public FAD though, as it was estimated that there are perhaps 22 total public and private FAD being used inside and outside of Municipal waters. The private FAD are not necessarily registered anywhere, and the owners are unknown. The private FAD, it was assumed, are more about the harvester than the regular hook and line visits, and will typically just check to see if fish are schooling, and then will utilize the harvester. The harvester is a large boat with a ring net that will be used when the fish are no longer biting at hook and line- meaning that there are many bait fish at the FAD.

The harvester cut described was quite different in this interview (this interviewee is more removed from the FAD harvests), saying that approximately $30 \%$ will go back to the community, and $70 \%$ will be taken by the harvester. The fish will be sold throughout 
Laoang, and sometimes elsewhere, depending on where the harvester sells. Sometimes as far away as the Bicol Region on Luzon. There are an excess of fish vendors in Laoang.

The FADs promote sustainable fishing for hook and line users. They are also necessary, the interviewee contended, to unload fishing pressures on the coastal areas of the municipality, and at the edge of municipal waters they are able to 'compete' with commercial fishing rigs (though commercial vessels need specific permission to fish municipal waters). When asked about environmental sustainability, interviewee responded that the FAD are environmentally sustainable because the species that are caught are migratory, and are only making 'stopovers' at the FAD.

Within the barangays, the fisherfolk are charged $20 \mathrm{PhP} /$ month as a fee with the local Fisherfolk Association. On top of this, the Mayors permit for a registered fisherfolk is $500 \mathrm{PhP} /$ year (USD 10). Additional fees are collected annually depending on the type of fishing gear used (60PhP for a Gillnet, other fees for different gears).

Profits managed through the Fisherfolk Association are distributed as $10 \%$ administrative, $10 \%$ maintenance, and $80 \%$ to the fisherfolk.

Catch is sold through the local fish vendors, and profit is distributed back through the fisherfolk that made the catch.

Given the national laws, a harvester can be used within the municipal waters only between 10.1 and $15 \mathrm{~km}$ from shore. No harvesters can be used 10km and below, and the municipality cannot regulate the FAD outside of $15 \mathrm{~km}$. It is required for good management to enact a municipal ordinance and to enforce this law, ensuring that the FAD are being used according to National Laws.

While the catch numbers are not reported to the municipality, the FFA tells the municipality which FADs will be harvested and when. Another important management necessity for the municipality is to regulate the months of catching (enacting open and closed seasons). This is especially important for female tuna. The migratory patterns of tuna need to be looked into. The interviewee noted that they had never observed fish with eggs being caught around Laoang.

Other important elements of project sustainability were to control the number of FAD, and the distances between the individual units (as well as their distance from shore). Enforcement is key. Another important variable is the regulation of the materials used in construction, to cut down on environmental impact.

In all, the FAD have shown a significant increase in the local fish catch of Pacific species. 


\section{A.3 Fish Catch Monitoring Data Summaries}

Included in this section are summaries of the fish catch monitoring data collection in Laoang for 2016 and 2017. The data has been compiled into Barangay specific reports, and is presented based on gear type and location (either in the coastal area or in the Pacific with the FADs). The Pacific Net data represents a highly seasonal activity in pursuit of flying fish.

The primary takeaway from FCM work in Laoang was the possibility of future data collection. A structure has been implemented that can be expanded upon in the future. General takeaways on local fish catch can also be taken from the project, though given the nature of the data collection specific analysis should be taken with reservations. Averages were not taken for gear types that had too few data points. 
BARANGAY CAHAYAGAN

\begin{tabular}{|l|l|l|l|l|l|}
\hline $\begin{array}{l}\text { Gear, } \\
\mathbf{2 0 1 6}\end{array}$ & $\begin{array}{l}\text { Average } \\
\text { Catch } \\
\text { (kg/trip) }\end{array}$ & $\begin{array}{l}\text { Average } \\
\text { Duration } \\
\text { (hrs) }\end{array}$ & $\begin{array}{l}\text { Average } \\
\text { Number of } \\
\text { Fisherfolk }\end{array}$ & $\begin{array}{l}\text { CPUE } \\
\text { (kg/ff/hr) }\end{array}$ & $\mathbf{n}$ \\
\hline $\begin{array}{l}\text { Pacific } \\
\text { Handline }\end{array}$ & 23.3 & 8.55 & 1.34 & 1.99 & 190 \\
\hline $\begin{array}{l}\text { Gear, } \\
\mathbf{2 0 1 7}\end{array}$ & \multicolumn{5}{|l|}{} \\
\hline $\begin{array}{l}\text { Pacific } \\
\text { Handline }\end{array}$ & 25.98 & 8.98 & 1.16 & 2.47 & 152 \\
\hline $\begin{array}{l}\text { Coastal } \\
\text { Net }\end{array}$ & .329 & 12 & 2 & .18 & 21 \\
\hline
\end{tabular}

\section{BARANGAY LANGOB}

\begin{tabular}{|c|c|c|c|c|c|}
\hline $\begin{array}{l}\text { Gear, } \\
2016\end{array}$ & $\begin{array}{l}\text { Average } \\
\text { Catch } \\
\text { (kg/trip) }\end{array}$ & $\begin{array}{l}\text { Average } \\
\text { Duration } \\
\text { (hrs) }\end{array}$ & $\begin{array}{l}\text { Average } \\
\text { Number of } \\
\text { Fisherfolk }\end{array}$ & $\begin{array}{l}\text { CPUE } \\
\text { (kg/ff/hr) }\end{array}$ & $\mathbf{n}$ \\
\hline $\begin{array}{l}\text { Pacific } \\
\text { Handline }\end{array}$ & 14.39 & 7.2 & 1.17 & 1.76 & 152 \\
\hline Pacific Net & 32.65 & 8.61 & 2.91 & 1.29 & 23 \\
\hline $\begin{array}{l}\text { Coastal } \\
\text { Net }\end{array}$ & 4.77 & 6.64 & 2.4 & .33 & 11 \\
\hline \multicolumn{6}{|l|}{$\begin{array}{l}\text { Gear, } \\
2017\end{array}$} \\
\hline $\begin{array}{l}\text { Pacific } \\
\text { Handline }\end{array}$ & 15.9 & 8 & 1.27 & 1.65 & 79 \\
\hline
\end{tabular}


BARANGAY INAMLAN

\begin{tabular}{|c|c|c|c|c|c|}
\hline $\begin{array}{l}\text { Gear, } \\
2016\end{array}$ & $\begin{array}{l}\text { Average } \\
\text { Catch } \\
\text { (kg/trip) }\end{array}$ & $\begin{array}{l}\text { Average } \\
\text { Duration } \\
\text { (hrs) }\end{array}$ & $\begin{array}{l}\text { Average } \\
\text { number of } \\
\text { Fisherfolk }\end{array}$ & $\begin{array}{l}\text { CPUE } \\
\text { (kg/ff/hr) }\end{array}$ & $\mathbf{n}$ \\
\hline $\begin{array}{l}\text { Coastal } \\
\text { Net }\end{array}$ & 9.19 & 4.77 & 2.3 & .82 & 127 \\
\hline Spear & 3.801 & 3.68 & 1.07 & .89 & 17 \\
\hline \multicolumn{6}{|l|}{$\begin{array}{l}\text { Gear, } \\
2017\end{array}$} \\
\hline $\begin{array}{l}\text { Coastal } \\
\text { Net }\end{array}$ & 6.22 & 4.67 & 2.08 & .63 & 71 \\
\hline Spear & 5.54 & 3.75 & 1 & 1.48 & 8 \\
\hline
\end{tabular}

\section{BARANGAY MARUBAY}

\begin{tabular}{|l|l|l|l|l|l|}
\hline $\begin{array}{l}\text { Gear, } \\
\mathbf{2 0 1 6}\end{array}$ & $\begin{array}{l}\text { Average } \\
\text { Catch } \\
\text { (kg/trip) }\end{array}$ & $\begin{array}{l}\text { Average } \\
\text { Duration } \\
\text { (hrs) }\end{array}$ & $\begin{array}{l}\text { Average } \\
\text { Number of } \\
\text { Fisherfolk }\end{array}$ & $\begin{array}{l}\text { CPUE } \\
\text { (kg/ff/hr) }\end{array}$ & n \\
\hline Spear & 3.39 & 5.6 & 1.58 & .46 & 36 \\
\hline $\begin{array}{l}\text { Coastal } \\
\text { Net }\end{array}$ & 5.89 & 3.66 & 2.37 & .75 & 24 \\
\hline $\begin{array}{l}\text { Coastal } \\
\text { Handline }\end{array}$ & 16.49 & 9.88 & 2.18 & .78 & 17 \\
\hline $\begin{array}{l}\text { Gear, } \\
\mathbf{2 0 1 7}\end{array}$ & & & & & 33 \\
\hline Spear & 6.38 & 5.27 & 1.39 & .76 & 23 \\
\hline $\begin{array}{l}\text { Coastal } \\
\text { Net }\end{array}$ & 5.5 & 3.68 & 2.69 & .8 & 11 \\
\hline $\begin{array}{l}\text { Coastal } \\
\text { Handline }\end{array}$ & 9.78 & 6.54 & 2 & .75 & \\
\hline
\end{tabular}




\section{BARANGAY CABADIANGAN}

\begin{tabular}{|l|l|l|l|l|l|}
\hline $\begin{array}{l}\text { Gear, } \\
\mathbf{2 0 1 6}\end{array}$ & $\begin{array}{l}\text { Average } \\
\text { Catch } \\
\text { (kg/trip) }\end{array}$ & $\begin{array}{l}\text { Average } \\
\text { Duration } \\
\text { (hrs) }\end{array}$ & $\begin{array}{l}\text { Average } \\
\text { Number of } \\
\text { Fisherfolk }\end{array}$ & $\begin{array}{l}\text { CPUE } \\
\text { (kg/ff/hr) }\end{array}$ & $\mathbf{n}$ \\
\hline $\begin{array}{l}\text { Coastal } \\
\text { Net }\end{array}$ & 8.14 & 5.75 & 3.66 & .38 & 41 \\
\hline Spear & 5.26 & 7.45 & 3.79 & .17 & 29 \\
\hline $\begin{array}{l}\text { Coastal } \\
\text { Handline }\end{array}$ & 10.07 & 8.64 & 1.64 & .72 & 14 \\
\hline $\begin{array}{l}\text { Gear, } \\
\mathbf{2 0 1 7}\end{array}$ & \multicolumn{5}{|l}{} \\
\hline $\begin{array}{l}\text { Coastal } \\
\text { Net }\end{array}$ & 9.96 & 6.26 & 3.63 & .47 & 37 \\
\hline Spear & 6.75 & 6.6 & 3.1 & .29 & 51 \\
\hline $\begin{array}{l}\text { Coastal } \\
\text { Handline }\end{array}$ & 9.16 & 11.5 & 1.1 & .73 & 12 \\
\hline
\end{tabular}

\section{BARANGAY NAPOTIOCAN}

\begin{tabular}{|c|c|c|c|c|c|}
\hline $\begin{array}{l}\text { Gear, } \\
2016\end{array}$ & $\begin{array}{l}\text { Average } \\
\text { Catch } \\
\text { (kg/trip) }\end{array}$ & $\begin{array}{l}\text { Average } \\
\text { Duration } \\
\text { (hrs) }\end{array}$ & $\begin{array}{l}\text { Average } \\
\text { number of } \\
\text { Fisherfolk }\end{array}$ & $\begin{array}{l}\text { CPUE } \\
\text { (kg/ff/hr) }\end{array}$ & $\mathbf{n}$ \\
\hline $\begin{array}{l}\text { Coastal } \\
\text { Net }\end{array}$ & 6.44 & 9.99 & 2.62 & .25 & 55 \\
\hline Spear & 3.94 & 7.6 & 1 & .52 & 15 \\
\hline $\begin{array}{l}\text { Coastal } \\
\text { Handline }\end{array}$ & 4.32 & 7.63 & 1 & .57 & 8 \\
\hline Pacific Net & 28.51 & 9.22 & 3.22 & .95 & 9 \\
\hline \multicolumn{6}{|l|}{$\begin{array}{l}\text { Gear, } \\
2017\end{array}$} \\
\hline $\begin{array}{l}\text { Coastal } \\
\text { Net }\end{array}$ & 5.26 & 6.61 & 2.38 & .32 & 39 \\
\hline Pacific Net & 17.13 & 8 & 2.91 & .65 & 12 \\
\hline
\end{tabular}


BARANGAY TAN-AWAN

\begin{tabular}{|l|l|l|l|l|l|}
\hline $\begin{array}{l}\text { Gear, } \\
\mathbf{2 0 1 6}\end{array}$ & $\begin{array}{l}\text { Average } \\
\text { Catch } \\
\text { (kg/trip) }\end{array}$ & $\begin{array}{l}\text { Average } \\
\text { Duration } \\
\text { (hrs) }\end{array}$ & $\begin{array}{l}\text { Average } \\
\text { number of } \\
\text { Fisherfolk }\end{array}$ & $\begin{array}{l}\text { CPUE } \\
\text { (kg/ff/hr) }\end{array}$ & $\mathbf{n}$ \\
\cline { 2 - 7 } Spear & 2.874 & 3.94 & 1 & .73 & 18 \\
\hline $\begin{array}{l}\text { Coastal } \\
\text { Net }\end{array}$ & 2.625 & 4 & 1.125 & .64 & 8 \\
\hline $\begin{array}{l}\text { Gear, } \\
\mathbf{2 0 1 7}\end{array}$ & \multicolumn{5}{|l|}{} \\
\hline Spear & 2.94 & 2.41 & 1.02 & 1.16 & 41 \\
\hline $\begin{array}{l}\text { Coastal } \\
\text { Net }\end{array}$ & 4.92 & 2.88 & 2.13 & .84 & 13 \\
\hline
\end{tabular}

\section{BARANGAY RAWIS}

\begin{tabular}{|c|c|c|c|c|c|}
\hline $\begin{array}{l}\text { Gear, } \\
2016\end{array}$ & $\begin{array}{l}\text { Average } \\
\text { Catch } \\
\text { (kg/trip) }\end{array}$ & $\begin{array}{l}\text { Average } \\
\text { Duration } \\
\text { (hrs) }\end{array}$ & $\begin{array}{l}\text { Average } \\
\text { number of } \\
\text { Fisherfolk }\end{array}$ & $\begin{array}{l}\text { CPUE } \\
\text { (kg/ff/hr) }\end{array}$ & $\mathbf{n}$ \\
\hline $\begin{array}{l}\text { Coastal } \\
\text { Net }\end{array}$ & 7.235 & 8.12 & 1.87 & .44 & 97 \\
\hline $\begin{array}{l}\text { Pacific } \\
\text { Handline }\end{array}$ & 34.74 & 12.07 & 2.15 & 1.4 & 14 \\
\hline \multicolumn{6}{|l|}{$\begin{array}{l}\text { Gear, } \\
2017\end{array}$} \\
\hline $\begin{array}{l}\text { Coastal } \\
\text { Net }\end{array}$ & 7.7 & 11.29 & 1.84 & .37 & 66 \\
\hline
\end{tabular}




\section{BARANGAY TALISAY}

\begin{tabular}{|c|c|c|c|c|c|}
\hline $\begin{array}{l}\text { Gear, } \\
2016\end{array}$ & $\begin{array}{l}\text { Average } \\
\text { Catch } \\
\text { (kg/trip) }\end{array}$ & $\begin{array}{l}\text { Average } \\
\text { Duration } \\
\text { (hrs) }\end{array}$ & $\begin{array}{l}\text { Average } \\
\text { number of } \\
\text { Fisherfolk }\end{array}$ & $\begin{array}{l}\text { CPUE } \\
\text { (kg/ff/hr) }\end{array}$ & $\mathbf{n}$ \\
\hline $\begin{array}{l}\text { Coastal } \\
\text { Net }\end{array}$ & 6.16 & 4.85 & 2.05 & .6 & 20 \\
\hline $\begin{array}{l}\text { Coastal } \\
\text { Handline }\end{array}$ & 23.41 & 10.81 & 1.5 & 1.46 & 16 \\
\hline \multicolumn{6}{|l|}{$\begin{array}{l}\text { Gear, } \\
2017\end{array}$} \\
\hline $\begin{array}{l}\text { Coastal } \\
\text { Net }\end{array}$ & 4.63 & 4.66 & 1.94 & .51 & 18 \\
\hline
\end{tabular}

\section{BARANGAY MUALBUAL}

\begin{tabular}{|c|c|c|c|c|c|}
\hline $\begin{array}{l}\text { Gear, } \\
2016\end{array}$ & $\begin{array}{l}\text { Average } \\
\text { Catch } \\
\text { (kg/trip) }\end{array}$ & $\begin{array}{l}\text { Average } \\
\text { Duration } \\
\text { (hrs) }\end{array}$ & $\begin{array}{l}\text { Average } \\
\text { number of } \\
\text { Fisherfolk }\end{array}$ & $\begin{array}{l}\text { CPUE } \\
\text { (kg/ff/hr) }\end{array}$ & $\mathbf{n}$ \\
\hline $\begin{array}{l}\text { Pacific } \\
\text { Handline }\end{array}$ & 26.72 & 10.34 & 1.34 & 2.04 & 76 \\
\hline $\begin{array}{l}\text { Coastal } \\
\text { Net }\end{array}$ & 5.28 & 3.95 & 2.75 & .46 & 20 \\
\hline Spear & 4.5 & 4.26 & 1.05 & .97 & 19 \\
\hline $\begin{array}{l}\text { Coastal } \\
\text { Handline }\end{array}$ & 3.99 & 6.61 & 1.5 & .42 & 14 \\
\hline \multicolumn{6}{|l|}{$\begin{array}{l}\text { Gear, } \\
2017\end{array}$} \\
\hline $\begin{array}{l}\text { Pacific } \\
\text { Handline }\end{array}$ & 34.37 & 12.34 & 1.26 & 2.19 & 110 \\
\hline $\begin{array}{l}\text { Coastal } \\
\text { Net }\end{array}$ & 4.21 & 3.65 & 1.36 & .83 & 11 \\
\hline Spear & 4.56 & 4.22 & 1.22 & .89 & 9 \\
\hline
\end{tabular}




\section{B Copyright documentation}

Figure 4.2: “Laoang Municipal Waters Map” made using Google Maps

https://www.google.com/maps/d/u/0/edit?mid=1IZM9Sdvenu_49_DqobgQWAkn5v_57

B_Z\&ll=12.396094019136843\%2C125.30808362617199\&z=9

Figures 1.2.1, 1.3, 3.2, and 4.1 are pictures taken by the author during his time in the Philippines. 